Article

\title{
Impact of Climate Smart Agriculture (CSA) Practices on Cotton Production and Livelihood of Farmers in Punjab, Pakistan
}

\author{
Muhammad Ali Imran 1,2 (1) Asghar Ali ${ }^{1, *}$, Muhammad Ashfaq ${ }^{1}$, Sarfraz Hassan ${ }^{1}$, \\ Richard Culas ${ }^{3}$ and Chunbo Ma ${ }^{2,4}$ \\ 1 Institute of Agricultural and Resource Economics, University of Agriculture, Faisalabad 38000, Pakistan; \\ aliimranshah1733@gmail.com (M.A.I.); ashfaq9@hotmail.com (M.A.); shassan63@uaf.edu.pk (S.H.) \\ 2 School of Agriculture and Environment, The University of Western Australia, Perth, WA 6009, Australia; \\ a2melbourne@163.com \\ 3 School of Agricultural and Wine Sciences, Charles Sturt University, Orange Campus, \\ Orange, NSW 2800, Australia; rculas@csu.edu.au \\ 4 Department of Economics, China Centre for Economic Development and Innovation Strategy, \\ College of Economics, Jinan University, Guangzhou 510632, China \\ * Correspondence: asghar.ali@uaf.edu.pk; Tel.: +92-333-831-0656
}

Received: 3 May 2018; Accepted: 25 May 2018; Published: 20 June 2018

check for updates

\begin{abstract}
Cotton is the second largest crop of Pakistan in terms of area after wheat and is being suffered by multiple shocks over the time due to conventional agricultural management practices, climate change, and market failures. Climate Smart Agriculture (CSA) was introduced by the Food and Agricultural Organization (FAO) in 2010, as an innovative cleaner production alternative to conventional farming that aimed at increasing the efficiency of natural resources, resilience, and productivity of agricultural production system, while reducing greenhouse gas emissions. The adverse effects of climate change on cotton production at the farm and regional level can be minimized by using CSA practices and technologies. The present study investigated the financial performance and explored the impact of CSA through sustainable water use management on cotton production in Lower Bari Doab Canal (LBDC) irrigation system of Punjab, Pakistan by using Cobb-Douglas production function. The adopters of CSA in cotton cultivation were identified by conducting six focus group discussions. Data were collected through well-structured questionnaire from 133 adopters of CSA and 65 conventional cotton growers for the cropping season 2016-2017. It was found that water-smart (raising crops on bed, laser land levelling, conjunctive use of water and drainage management), energy-smart (minimum tillage), carbon-smart (less use of chemicals) and knowledge-smart (crop rotation and improved varieties i.e., tolerant to drought, flood and heat/cold stresses) practices and technologies of CSA were adopted by the cotton farmers in the study area. Most of the farmers were of the view that they are adopting CSA practices and technologies due to the limited supply of canal water, climate change, drought-prone, massive groundwater extraction, rapidly declining groundwater table and increasing soil salinity over the time. Results revealed that uniform germination, higher yield and financial returns, the concentration of inputs and increase in resource use efficiency are the main advantages of CSA. The econometric analysis showed that implementation of CSA practices and technologies as judicious use of water and fertilizer, groundwater quality, access to extension services, and appropriate method and time of picking have a significant impact on the gross value of cotton product (GVP). The findings of the study would be helpful for policy makers to formulate policies that can minimize farmer's financial burden to adopt CSA technologies and implement for scaling out in Punjab and beyond.
\end{abstract}


Keywords: climate smart agriculture; production function; Lower Bari Doab Canal (LBDC) irrigation system; gross value of cotton product; Punjab; climate change

\section{Introduction}

Like many other developing countries, agriculture in Pakistan is the second largest sector after service sector by contributing 19.5 percent to GDP and employs around 42 percent of the total labor force [1]. Agriculture is important for ensuring food security and reducing poverty. Low performance of this sector in Pakistan may be attributed to various factors such as high population growth, food insecurity, conventional agricultural management practices, slow rate of technological innovation, limited adoption of progressive farming techniques [2], water scarcity, rapid urbanization, dominance of small land holdings [3] and climate change induced impacts, i.e., rising temperatures, droughts, floods and uneven pattern of rainfall [1,4-6]. It is well documented that groundwater is under rapid depletion in Pakistan like other countries [7-9]. According to an estimate, annual total irrigated water use is about $151 \mathrm{Km}^{3}$ /year, which is more than 95 percent of the total withdrawal in Pakistan [10]. Water scarcity in the country is increasing and the regular occurrence of drought is posing a threat to the agricultural economy specifically. The main reasons of water scarcity in the country are silting of major reservoirs, high population growth, poor irrigation management, climate change phenomenon and lack of consensus among the provinces on the construction of new dams [10,11].

Agriculture sector in Pakistan is climate-sensitive and highly vulnerable to increasing weather variability and climate change and thereby, have become major barriers to achieving food security and alleviating poverty in Pakistan [12]. Several studies indicated that production of major crops in Pakistan could be significantly impacted due to receiving less rainfall, increase in temperature across the country by $0.5^{\circ} \mathrm{C}$ in the past three decades [3] and variations in frequency and intensity of droughts and floods over the period of 1995-2017 [3,5,6]. Similarly, projections indicate that mean increase of temperature in Pakistan is higher than the expected global average $\left(1.4^{\circ} \mathrm{C}-3.7^{\circ} \mathrm{C}\right)$.

Majority of the farmers in Pakistan are still practicing conventional agriculture [13-15]. Additionally, they are producing cotton using conventional agricultural management practices (applying high dose of fertilizers, pesticides and water etc.). Consequently, the conventional cotton farmers have higher cost of production and low resource use efficiency $[13,14,16]$. This study used data of conventional cotton growers to refer the cotton production, using intensive amount of external inputs.

In Pakistan, cotton is the most important and the second largest cash crop in terms of area after wheat, contributing one percent in the total GDP and 6.5 percent in the agricultural value addition. It is an important source of foreign exchange and main source of raw material to textile sector [1]. Although Pakistan is the world's fourth largest producer of cotton, yet this crop is climate-sensitive and suffered multiple shocks over the time due to conventional agricultural management practices, climate change, and market failures. Cotton crop is badly affected by climate change in Pakistan due to excessive irrigation water use along with intensive pesticide and fertilizer application $[1,13,17]$. Most of the researchers found that production of cotton in Pakistan is negatively affected by climate change [13,18-20] and inefficient cotton production management practices [13-16]. The increased vulnerability of cotton crop to insect and pest attacks, declining crop yields, excessive use of groundwater, deterioration of natural resources and human health due to chemical based conventional agriculture have raised concerns about the long-term sustainability of the system [13-15,18,21].

Because of social, environmental and economic problems arising from climate change and conventional agriculture, FAO has prompted a sustainable agricultural production system i.e., Climate-Smart Agriculture (CSA) an alternative to conventional agriculture. CSA improves the efficiency of natural resources, increased resilience and productivity of agriculture, and reduce greenhouse gas emissions [22]. The technology or practice that helps to increase productivity and 
farm income, improves water and nutrient use efficiency, resilience to climate change, and reduced greenhouse gas emissions is called CSA [22-28]. The adverse effect of variability in climatic conditions on agriculture can be reduced substantially by adopting CSA practices and technologies individually or in combination $[3,12,23,24]$. Therefore, the adoption of CSA in cotton production can improve yield, enhance resource use efficiency and farm income as well as minimize the adverse effects of climate change on its production.

Empirical studies from developed and developing countries like India have shown that simple adaptation of CSA can increase agricultural productivity and farm income. This implies that changes in cropping pattern, planting dates, adoption of new agricultural and water saving technologies have significant impact on agricultural productivity and farm income [16,23,24,29-32]. Similarly, many empirical studies from developed and developing countries shows that applications of CSA practices and technologies increased crop yield, resource use efficiency, net farm income, and reduced greenhouse gas emissions [24,33-41]. Additionally, a few studies from Pakistan found that implementation of new agricultural practices and technologies, and adaptation to climate change significantly influencing the agricultural productivity, farm income and resource use efficiency $[12,15,16,32,42-44]$. Similarly, many researchers [10,45-47] also found that groundwater quality varies across the farms and regions and have significant impact on agricultural productivity, farm income and livelihood of rural households in Pakistan. Water-smart, energy-smart, carbon-smart and knowledge-smart CSA practices and technologies are now being adopted by farmers in Pakistan [3].

The agricultural practices and technologies are considered as climate-smart that can help to achieve at least one pillar of CSA. Three basic pillars of CSA are increased productivity, resilience to climate change and reduced greenhouse gas emission. The cultivation of cotton in Pakistan suffered multiple shocks i.e., market failures, climate change and poor agricultural management practices resulting substantial decrease in crop production [1]. It has been observed that implementation of CSA significantly minimized the adverse effects of climatic stresses, increase crop productivity, farm income and cropped area.

The rate of adoption of CSA practices and technologies is significantly influenced by economic benefits, socio-economic characteristics, operational land holding, groundwater quality and scarcity, type of ownership, credit access and extension services $[5,6,12,16,23,24,32,42,44]$. The goal of this study is to estimate the impact of climate-smart agriculture (CSA) through sustainable irrigation management on cotton production and livelihood of farmers in Punjab, Pakistan. There exist few studies on the implementation of new agricultural practices and technologies, and adaptation to climate change in Pakistan $[12,15,16,24,32,42-44]$. Nevertheless, those studies focus on any new technology and practice with an objective to estimate the benefits and costs of adoption of that technology. This study is, to the best of knowledge, the first quantitative research to estimate the impact of climate-smart agriculture (CSA) through sustainable irrigation management on cotton production and livelihood of farmers in Punjab, Pakistan as well as provide some suggestions for policy makers for the promotion of CSA in Punjab and rest of the cotton growing area.

\section{Materials and Methods}

\subsection{Data Information and Salient Features of the Study Area}

This study is carried out in two irrigation divisions viz. Sahiwal and Khanewal in the command areas of LBDC irrigation system of Punjab, Pakistan (Figure 1), which covers 0.8 million hectares (Mha) along Bari Doab and is the second largest irrigation system of Punjab [48]. Punjab province is the major producer of cotton having 80 percent share in total production fallowed by Sindh [1]. Rice-Wheat, Cotton-Wheat, Maize-Maize and Maize-Wheat are the major cropping systems of this irrigation system. 


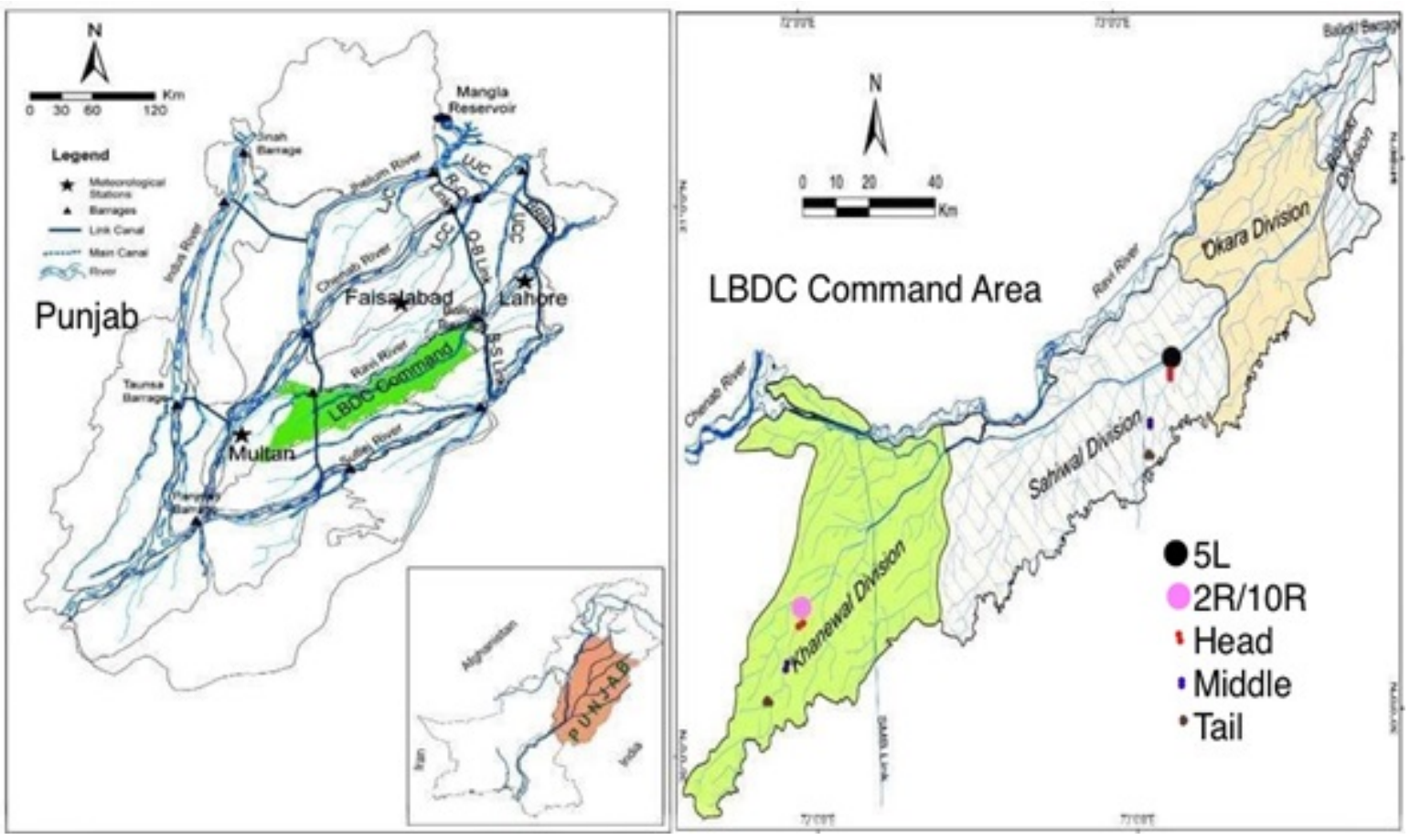

Figure 1. Map of study area (Sahiwal and Khanewal) and Lower Bari Doab Canal (LBDC) command area.

The study used a primary dataset, collected in 2017 using multi-stage sampling technique from 198 cotton farmers in the study area. In the second stage, one distributary/minor (5L and 2R/10R distributary was selected from Sahiwal and Khanewal irrigation division, respectively). In the third and the fourth stages, watercourses ( 2 from head, middle and tail of each distributary/minor, 12 total) and villages (16 total) were randomly selected (Table 1). From each village 8-10 adopters of CSA in cotton production and 4-5 conventional cotton farmers were randomly selected, resulting in 198 cotton farmers i.e., 133 adopters of CSA in cotton production and 65 conventional cotton farmers. The study also conducted three Focus Group Discussions (FGDs) by engaging local Farmer's Organizations (FOs) and local leaders i.e., Nambardar (village headman nominated by the government) in each selected distributary (head, middle and tail) to identify the adopters of CSA in cotton production. The number of participants in each FGD were 25-30, of different age group, gender, income level, agriculture characteristics and geographic location along the canal. The surveyed villages had more than 50 percent of farmers using CSA practices and technologies. The field visits of that particular area found around 12 percent conventional cotton farmers from each village destroyed their cotton crop at early stage and after first picking due to abrupt weather changes, insect pest attack and poor management practices [1]. Due to these reasons the sampled population of conventional cotton farmers from each village was small compared to adopters of CSA.

Table 1. Sampling framework of the study area.

\begin{tabular}{ccc}
\hline Irrigation Divisions of LBDC Sampled & Sahiwal & Khanewal \\
\hline Distributaries sampled & $5 \mathrm{~L}$ & $2 \mathrm{R} / 10 \mathrm{R}$ \\
Number of focus group discussion conducted & 3 & 3 \\
Number of participant in each focus group discussion & $25-30$ & $25-30$ \\
Number of watercourses sampled & 6 & 6 \\
Number of villages sampled & 6 & 10 \\
Number of respondents sampled & 48 & 150 \\
\hline
\end{tabular}

Source: Own calculation from survey data, 2017. 
In the study area, Cotton-Wheat is the dominant cropping system as majority of the farmers grow cotton (47 percent in Khanewal and 20 percent in Sahiwal) and Wheat (51 percent in Khanewal and 46 percent in Sahiwal) as major crops during Kharif and Rabi seasons [48]. The production of cotton in the study area is adversely affected by climate change, soil salinity, drought prone, water shortage and quality, lowering depth of water table and massive extraction of groundwater due to arid and semi-arid geographic location. Due to these reasons the sampled population of conventional cotton farmers from each village was small compared to adopters of CSA. The surface and groundwater are used by the farmers to fulfill the irrigation water requirement for cotton crop in the study area. Groundwater is a main source of irrigation for agriculture as partial canal water supplies are available. In both distributaries, this study found that the contribution of canal water during the Kharif cropping season of 2016-2017 was 25-40 percent of the total irrigation requirements for Kharif crops.

Additionally, both distributaries received very low rainfall. On average, $5 \mathrm{~L}$ and $2 \mathrm{R} / 10 \mathrm{R}$ distributary received $160 \mathrm{~mm}$ and $80 \mathrm{~mm}$ annual rainfall, respectively. Therefore, groundwater was used as a main source of irrigation. The water table and bore depth were observed to range between 14-20 m and 50-60 $\mathrm{m}$ in both distributaries. The sample data also showed that the range of groundwater mining is $0.34-0.70 \mathrm{~m}$ /year. Because of lower water table, the tubewell installation cost and groundwater extraction cost is rising in both distributaries. It has been observed that groundwater quality varies across the canal command area, usually head farms have good groundwater quality (fit) compared to middle and tail ends (marginal fit-unfit) in both distributaries. The adopters of CSA in cotton production and conventional cotton farmers were interviewed at their farm premises by using a well-structured questionnaire. The data on climate change, groundwater quality, groundwater and surface water supplies, socio-economic characteristics, farm and household information, impact of various CSA practices and technologies on crop yield and farm income were collected from both adopters of CSA in cotton production and conventional cotton farmers in each selected village. In addition, supplementary information related to climate change, irrigation water, geographic, and farm characteristics and CSA practices and technologies were collected from the members of local Farmer's Organizations (FOs) and local leaders. Similarly, data on groundwater quality and depth of water table during Kharif and Rabi season 2016-2017 of both distributaries were collected from the Directorate of Land Reclamation (DLR), Punjab. This department collect data on groundwater quality and depth of water table twice a year i.e., Pre-monsoon (May-June) and Post-monsoon (October-November). The study also observed that various CSA practices and technologies i.e., water-smart, energy-smart, carbon-smart and knowledge-smart were widely adopted by the cotton farmers in both distributaries.

\subsection{Financial Performance: Cost and Benefits}

The conventional cost and benefit method are used to analyze the financial performance of adopters of CSA in cotton cultivation and conventional cotton growers. The cost of production of cotton farmers included the cost of all inputs (e.g., seed, land preparation, sowing, intercultural operations, land rent, fertilizer, irrigation, pesticides, weedicides, farm yard manure, micro-nutrients, labor wages (family and hired) and picking) used in the production process of cotton. The opportunity cost is used in case of farmers have their own land, farm machinery, seed and family labor. Similarly, total revenue (also called Gross Value Product (GVP)) is also calculated. This study used $t$-test assuming unequal variances for comparing the mean values of two-groups. [14,15,21,49]. By using unequal variances, the proportion of adopters and conventional cotton farmers do not pose any biasness. Following $[15,32,45,47,50]$, estimation methods of net return and Benefit Cost Ratio (BCR) are as under.

$$
\begin{gathered}
\text { Net Return = Total Revenue (TR) }- \text { Total Cost }(\mathrm{TC}), \\
\mathrm{BCR}=\text { Total Revenue }(\mathrm{TR}) / \text { Total Cost }(\mathrm{TC}),
\end{gathered}
$$




\subsection{Econometric Model}

Cobb-Douglas production function is being employed by many researchers $[10,32,45-47,51]$ to investigate the impact of different socio-economic factors and physical inputs on crop yield. This study used double-log production model to find the impact of climate-smart agriculture through sustainable water use management on cotton production in Lower Bari Doab Canal (LBDC) irrigation system of Punjab, Pakistan. The double-log production model is given in the form of equation:

$$
\begin{aligned}
\operatorname{lnGVP}=\gamma_{0}+ & \gamma_{1} \ln \mathrm{X}_{1}+\gamma_{2} \ln \mathrm{X}_{2}+\gamma_{3} \ln \mathrm{X}_{3}+\gamma_{4} \ln \mathrm{X}_{4}+\gamma_{5} \ln \mathrm{X}_{5}+\gamma_{6} \ln \mathrm{X}_{6}+\gamma_{7} \ln \mathrm{X}_{7} \\
& +\gamma_{8} \ln \mathrm{X}_{8}+\gamma_{9} \mathrm{DCSA}+\gamma_{10} \mathrm{DCA}+\gamma_{11} \text { DExt. }+\varepsilon_{\mathrm{i}},
\end{aligned}
$$

where $\ln G V P=\log$ of gross value of cotton production (PKR/acre).

$\operatorname{LnX}_{1}=\log$ of farm experience of respondent (years)

$\operatorname{Ln} X_{2}=$ cotton area (acre)

$\operatorname{LnX}_{3}=$ seed cost $(\mathrm{PKR} / \mathrm{acre})$

$\operatorname{LnX}_{4}=$ land preparation cost (PKR/acre)

$\operatorname{LnX}_{5}=$ fertilizer cost $(\mathrm{PKR} / \mathrm{acre})$

$\operatorname{LnX} X_{6}=$ tubewell irrigation cost $(\mathrm{PKR} /$ acre $)$

$\operatorname{Ln} \mathrm{X}_{7}=$ picking $\operatorname{cost}(\mathrm{PKR} / \mathrm{acre})$

$\operatorname{LnX}_{8}=$ electrical conductivity (EC), used for groundwater quality $(\mathrm{dS} / \mathrm{m})$

DCSA = dummy variable, 1 for adopters of CSA in cotton cultivation and 0 otherwise

DCA = dummy variable, 1 for access to credit and 0 otherwise

DExt. = dummy variable, 1 for access to extension services and 0 otherwise

$\varepsilon_{\mathrm{i}}=$ error term

\section{Results and Discussion}

\subsection{Summary Statistics of Farm and Socio-Economic Characteristics}

Summary statistics of farm and socio-economic characteristics of adopters of CSA in cotton production and conventional cotton farmers are given in Table 2. The results showed that there is significant difference in the respondent's age, farming experience, educational level, operational land holding, and family workers involved in farming and picking cost between adopters of CSA in cotton production and conventional cotton farmers. Table 2 also shows that there is not a significant difference in family size, area under cotton cultivation and groundwater quality of both farmer groups. The adopters of CSA in cotton production have significantly higher farming experience compared to conventional cotton farmers i.e., 20.68 and 16.65 years, respectively.

Table 2. Summary statistics of farm and socio-economic characteristics.

\begin{tabular}{ccc}
\hline Variables & \multicolumn{2}{c}{ Cotton Farmers } \\
\cline { 2 - 3 } & $\begin{array}{c}\text { Adopters of CSA } \\
(\mathbf{N}=\mathbf{1 3 3})\end{array}$ & $\begin{array}{c}\text { Conventional } \\
(\mathbf{N}=\mathbf{6 5})\end{array}$ \\
\hline Respondent age (years) & $45.72^{* *}$ & $42.558^{* *}$ \\
Farming experience (years) & $20.68^{* * *}$ & $16.65^{* * *}$ \\
Education (schooling years) & $6.34^{* * *}$ & $5.49^{* * *}$ \\
Family size (Nos.) & 8.85 & 8.28 \\
Operational land holding (acre) & $11.72^{* * *}$ & $9.35^{* * *}$ \\
Cotton area (acre) & 8.89 & 8.37 \\
Access to extension services (Yes $=1, \mathrm{No}=0)$ & 56.39 & 43.08 \\
Access to credit services (Yes =1, No = 0) & 51.12 & 75.38 \\
Electrical conductivity (EC), used for groundwater quality (dS/m) & 1.12 & 1.17 \\
Power ownership (Own =1, No = 0) & 45 & 29 \\
Family labor involved in farming (Nos.) & $1.23^{* * *}$ & $2.26^{* * *}$ \\
\hline
\end{tabular}

Source: Own calculation from survey data, 2017. Note: ${ }^{* * *} p<0.01,{ }^{* *} p<0.05$, respectively for two-group mean comparison $t$-test assuming unequal variances. 
The results showed that average schooling years of adopters and conventional cotton farmers are 6.34 and 5.49, respectively. The results also showed that adopters possessed large operational land holding (11.72 acres) compared to conventional cotton farmers (9.35 acres). The power ownership, access to credit and extension services is included as dummy variable. The results showed that 45 percent of adopters of CSA in cotton production had their own power source compared to conventional cotton farmers ( 29 percent). However, the adopters of CSA have greater access to credit and extension services compared to conventional cotton growers in the study area. The results also showed that a higher number of family labor involved in the cultivation of cotton negatively influenced the production. The conventional cotton farmers underutilize the family labor because cultivation of cotton at small scale does not required more than two-full time workers during the whole cultivation period [16]. This implies that majority of the adopters of CSA in cotton production have regular contact with extension agents, while some of the conventional cotton farmers have not visited extension offices at all.

\subsection{Level of Input Use by Cotton Farmers}

The adopters of CSA in cotton production significantly used less amount of mechanical operations, seed, fertilizer, irrigation, pesticides and weedicides compared to conventional cotton farmers (Table 3). Additionally, the adopters of CSA used higher amount of Farm Yard Manure (FYM) and Gypsum compared to conventional farmers. The results showed that 36 percent farmers used deep ploughing due to clay loam soil while all adopters of CSA used bed planter and laser land levelling for land preparation. The use of seed rate was significantly varied by farmer's group. The average seed rate used by adopters of CSA and conventional cotton farmers is 7.69 and $9.88 \mathrm{~kg}$ per acre, respectively. There is considerable difference in the number of bags of fertilizers applied to cotton crop between farmer's group (Table 3). The average number of bags of fertilizers used by adopters of CSA in cotton production is significantly less than conventional cotton farmers. This implies that conventional cotton farmers had higher dependency on fertilizers. The results showed that both adopters of CSA and conventional cotton farmers applied almost equal number of irrigations to cotton crop. These results are in line with previous studies [15,24,32].

The adopters of CSA are using significantly less amount of water $\left(2486.32 \mathrm{~m}^{3}\right)$ compared to conventional cotton farmers $\left(3205.87 \mathrm{~m}^{3}\right)$. Per irrigation average time is 1.23 and $1.91 \mathrm{~h}$ for adopters of CSA and conventional cotton farmers, respectively. The use of intercultural operations by adopters of CSA is found to be significantly less compared to conventional cotton farmers. This implies that the germination and growth rate of plants is higher in bed sowing compared to drill sowing of cotton. The adopters of CSA commonly used the FYM and Gypsum in cotton production due to variation in groundwater quality. The results of this study are consistent with previous literature [15,24,32]. Additionally, there is considerable difference in the frequency of weedicide and pesticide sprays applied to cotton crop between farmer's groups. The average number of weedicide and pesticide applied by adopters of CSA and conventional cotton farmers are 3.97 and 6.72, respectively. The use of manual and mechanical methods to eradicate weeds is common among the adopters of CSA in cotton production. This implies that humidity is very low due to water scouting in the study area that is the main reason of less number of pesticides sprays applied by adopters of CSA in cotton production. The total cost (own land) of adopters of CSA is slightly lower and statistically non-significant compared to convention cotton farmers. Notably, even with less use of inputs and total cost, the adopters of CSA have significantly higher yield compared to conventional cotton farmers (Table 4). These findings of the study are in line with previous literature [13,15,32]. Hence, these results indicated that the significant amount of inputs is saved in CSA which reduced per acre cost of production, increased farm income and as well as efficiency of resource use. 
Table 3. Level of inputs use by cotton farmers (per acre).

\begin{tabular}{|c|c|c|c|}
\hline \multirow{2}{*}{ Inputs } & \multirow{2}{*}{ Unit } & \multicolumn{2}{|c|}{ Cotton Farmers } \\
\hline & & Adopters of CSA $(N=133)$ & Conventional $(N=65)$ \\
\hline 1. Land preparation & Nos. & $4.83^{* * *}$ & $4.28^{* * *}$ \\
\hline Deep plough & Nos. & 0.24 & 0.00 \\
\hline Rotavator & Nos. & 0.76 & 0.88 \\
\hline Ploughing & Nos. & 2.13 & 2.40 \\
\hline Planking & Nos. & 0.70 & 1.00 \\
\hline Laser land leveling & Nos. & 1.00 & 0.00 \\
\hline 2. Seed rate & Kgs & $7.69^{* * *}$ & $9.88^{* * *}$ \\
\hline 3. Fertilizers $(1 \mathrm{Bag}=50 \mathrm{~kg})$ & Bags & $3.86^{* * *}$ & $4.98^{* * *}$ \\
\hline DAP & Bags & 1.22 & 1.45 \\
\hline Nitro-Phosphate & Bags & 0.09 & 0.24 \\
\hline Urea & Bags & 2.25 & 2.80 \\
\hline Potash & Bags & 0.24 & 0.15 \\
\hline Other (NPK) & Bags & 0.06 & 0.34 \\
\hline 4. Irrigation Water & $\mathrm{m}^{3}$ & $2486.32 * * *$ & $3205.87 * * *$ \\
\hline Canal Water & $\mathrm{m}^{3}$ & 1375.6 & 1674.69 \\
\hline Tubewell Water & $\mathrm{m}^{3}$ & 1110.72 & 1531.18 \\
\hline 5. Time required/irrigation & Hours & $1.23^{* * *}$ & $1.91^{* * *}$ \\
\hline 6. Intercultural operations & Nos. & $3.20 * * *$ & $4.09^{* * *}$ \\
\hline Manual thinning and Hoeing & Nos. & 0.70 & 0.74 \\
\hline Ridger & Nos. & 2.50 & 3.35 \\
\hline 7. Farm Yard Manures (FYM) & Nos. of trolleys & 0.89 & 0.72 \\
\hline 8. Gypsum & Bags & $0.77^{* * *}$ & $0.54^{* * *}$ \\
\hline 9. Weedicides and insecticides & Nos. & $3.97^{* * *}$ & $6.72 * * *$ \\
\hline Weedicides spray & Nos. & 0.86 & 1.00 \\
\hline Insecticides spray & Nos. & 3.11 & 5.72 \\
\hline
\end{tabular}

Source: Own calculation from survey data, 2017. Note: ${ }^{* * *} p<0.01$ for two-group mean comparison $t$-test assuming unequal variances.

Table 4. Cost and benefit analysis of cotton production (PKR ${ }^{1} /$ acre).

\begin{tabular}{|c|c|c|}
\hline \multirow{2}{*}{ Costs and Benefits } & \multicolumn{2}{|c|}{ Cotton Farmers } \\
\hline & Adopters of CSA $(N=133)$ & Conventional $(N=65)$ \\
\hline \multicolumn{3}{|c|}{ Costs } \\
\hline Land Rent (for rented land) & $11,063.91 * * *$ & $9734.62 * * *$ \\
\hline Land Preparation Cost & $4149.59 * * *$ & $3186.54 * * *$ \\
\hline Seed and Sowing Cost & $5006.47^{* * *}$ & $3910.23^{* * *}$ \\
\hline Irrigation Cost & $6620.03 * * *$ & $8651.13^{* * *}$ \\
\hline Intercultural Operations Cost (thinning, hoeing and ridger) & $2480.68^{* * *}$ & $3019.23 * * *$ \\
\hline Fertilizer Cost & $7697.89 * * *$ & $9470.96^{* * *}$ \\
\hline FYM Cost & 632.71 & 507.69 \\
\hline Chemical Cost (Gypsum, weedicides and insecticides) & $4175.64^{* * *}$ & $6936.15^{* * *}$ \\
\hline Cotton picking cost $(\mathrm{PKR} / \mathrm{kg})$ & $9.19^{* * *}$ & $8.28^{* * *}$ \\
\hline Total Cotton-Picking Cost (Yield ${ }^{*}$ Cotton picking cost per kg) & $9249.62 * * *$ & $7216.92 * * *$ \\
\hline Labor Cost (family and hired) & $10,597.80 * * *$ & $8069.76^{* * *}$ \\
\hline Total Cost (TC) (rented land) & $61,674.33 *$ & $60,703.24 *$ \\
\hline Total Cost (TC) (own land) & $50,610.42$ & $50,968.62$ \\
\hline \multicolumn{3}{|c|}{ Benefits } \\
\hline Yield (kg/acre) & $1005.71^{* * *}$ & $872.31^{* * *}$ \\
\hline Price (PKR/kg) & 72.01 & 72.02 \\
\hline Total Revenue (TR) & $72,390.23 * * *$ & $62,761.85 * * *$ \\
\hline Net Return (TR-TC) (rented land) & $10,715.90 * * *$ & $2058.61 * * *$ \\
\hline Net Return (TR-TC) (own land) & $21,779.81 * * *$ & $11,793.22 * * *$ \\
\hline BCR (rented land) & $1.18 * * *$ & $1.04 * * *$ \\
\hline BCR (own land) & $1.44 * * *$ & $1.24 * * *$ \\
\hline
\end{tabular}

Source: Own calculation from survey data, 2017. Note: ${ }^{* * *} p<0.01, * p<0.1$, respectively for two-group mean comparison $t$-test assuming unequal variance. ${ }^{1}$ This study uses the average exchange rate for the year 2017 $(1 \mathrm{PKR}=0.01 \mathrm{USD})$, when the survey was carried out. 


\subsection{Cost and Benefit Analysis of Cotton Production}

This study found that there is significant difference in the costs of production and benefits (farm income) between farmer's group i.e., adopters of CSA and conventional cotton farmers. The results showed that conventional cotton farmers have significantly higher cost of external inputs (irrigation, intercultural operations, fertilizer and chemical) compared to adopters of CSA in cotton production (Table 4). The adopters of CSA in cotton production incurred higher costs in land rent, land preparation, seed and sowing, and labor because of laser land levelling, bed planter used and skilled worker, respectively compared to convention cotton farmers. The land rent for adopters is higher than conventional cotton farmers because of the fact that most of the adopters of CSA have valued farms e.g., lined watercourse, good groundwater quality, regular canal water supply, electric tubewells, paved farm to market road, better fertile and levelled land compared to conventional cotton farms in the study area. Additionally, the land rent is also depending on the farm location with respect to watercourse and distributary i.e., head farmers have higher land rent compared to middle and tail. The adopters of CSA are using the certified seed (improved varieties that are tolerant to drought, flood and heat/cold stresses) rather conventional seed. The cost of certified seed is higher than conventional seed, but per acre seed cost of farmers group is almost same because of adopters of CSA used less seed $(7.69 \mathrm{~kg} /$ acre $)$ compared to conventional cotton farmers $(9.88 \mathrm{~kg} / \mathrm{acre})$. This increase in seed and sowing cost is due to the reason that adopters of CSA are using bed planting sowing method. Additionally, the conventional cotton farmers have little higher total cost of production than adopters of CSA, due to excessive use of external inputs i.e., seed rate, irrigation, fertilizer, chemical. But there is no significant difference between the total costs of both farmer's group. The results of the study are in line with previous literature $[13,15,32]$.

The adopters of CSA in cotton production have significantly higher average yield (13 percent) and enjoyed a higher net income as compared to conventional cotton farmers. The net return is 21,780 and 11,793 PKR/acre for adopters of CSA and conventional cotton farmers, respectively. The entire results showed the absolute advantage of CSA over conventional cotton farming. Hence, cotton production by using CSA practices and technologies is financially, environmentally and socially far better than conventional cotton cultivation. The adopters of CSA have significant higher benefit cost ratio as compared to conventional cotton farmers. The BCR resulted that the adopters of CSA and conventional cotton farmers have financial return between 1.18 to 1.44 and 1.02 to 1.24 per unit of input cost, respectively. This implies that CSA is financially superior to conventional agriculture. The results of the study are in line with previous literature $[13,15]$.

\subsection{Econometric Analysis}

The impact of CSA through sustainable irrigation management on cotton production and livelihood of farmers in Punjab, Pakistan has been analyzed by using the Cob-Douglas (log-log) production function. The results of the analysis with Gross Value Product (GVP) of cotton as dependent variable and operational costs, socio-economic characteristics, institutional factors, water quality and CSA as explanatory variables are presented in Figure 2 and Table 5. The coefficient plot (Figure 2) of regression analysis showed that the operational costs i.e., fertilizer, tubewell irrigation and cotton picking, access to extension services and CSA practices and technologies have positive and significant impact on gross value of cotton product while groundwater quality have negatively significant impact on gross value of cotton product. The results of the analysis also showed that farming experience, cotton area, access to credit, seed and land preparation costs have insignificant impact on gross value of cotton product (Figure 2). This implies that non-significant impact of farming experience on gross value of cotton product could be due to age factor and low level of education. As old farmers are reluctant to adopt new technologies easily and strictly following the conventional agricultural practices. 




Figure 2. Coefficient plot without intercept of regression analysis. Note: the "•" shows the estimated value of the explanatory variable while horizontal line along with "•" shows the standard error of each variable. Smaller the line means higher the level of significance of the variable and vice versa.

Farming experience had non-significant impact on the gross value of wheat product in Pakistan [45]. The coefficients of cost of seed and land preparation are negative and non-significant because of conventional agriculture practices. The results already showed that conventional cotton farmers used more seed rate and mechanical operations compared to adopters of CSA. These results are in line with literature $[10,13,15,32]$. The cotton area and access to credit have non-significant impact on gross value of cotton product because of market failure and misuse of credit, respectively [44].

Table 5. Econometric Analysis.

\begin{tabular}{ccc}
\hline Explanatory Variables & Model & Robust Standard Errors \\
\hline $\ln X_{1}$ & 0.00315 & 0.00745 \\
$\ln X_{2}$ & 0.0114 & 0.00893 \\
$\ln X_{3}$ & -0.00264 & 0.00955 \\
$\ln X_{4}$ & -0.0564 & 0.0347 \\
$\ln X_{5}$ & $0.0630^{* *}$ & 0.0287 \\
$\ln X_{6}$ & $0.00403^{* *}$ & 0.00187 \\
$\ln X_{7}$ & $0.441^{* * *}$ & 0.0338 \\
$\ln X_{8}$ & $-0.0518^{* * *}$ & 0.0157 \\
DCSA & $0.0271^{* * *}$ & 0.00901 \\
DCA & 0.00140 & 0.00676 \\
DExt. & $0.0134^{*}$ & 0.00684 \\
Constant & $3.019^{* * *}$ & 0.207 \\
Observations & 198 & \\
R-squared & 0.715 & \\
\hline
\end{tabular}

Source: Own calculation from survey data, 2017. Note: ${ }^{* *} p<0.01,{ }^{* *} p<0.05,{ }^{*} p<0.1$. Dependent Variable $=$ $\ln G V P=\log$ of gross value of cotton product.

Table 5 shows that the coefficient of fertilizer cost showed positive and significant relationship with cotton yield. The magnitude of fertilizer coefficient is 0.063 , which means one percent increase in expenditures on fertilizer use, gross value of cotton product increased by 0.063 percent. Many researchers $[10,32,45,47]$ found that fertilizer had positive and significant impact on agricultural productivity. The tubewell irrigation cost is highly significant which explained that by one percent 
increase in cost of tubewell irrigation, there is 0.004 percent increase in the gross value of cotton product. This implies that groundwater quality is fit for irrigation, and cotton farmers can increase yield by using groundwater for irrigation purpose efficiently because canal water supply is limited in the study area. The previous literature also second these findings [32].

The cotton-picking cost is highly significant which implies that one percent increase in cotton picking cost, gross value of cotton product increased by 0.441 percent because it depends on cotton yield. The average cost paid by the adopters of CSA and conventional cotton farmers to female cotton pickers is 9.19 and $8.28 \mathrm{PKR} / \mathrm{kg}$, respectively in the study area. The coefficient of groundwater quality showed that it has negative and significant relationship with cotton yield. The results showed that gross value of cotton product can be decreased by 0.0518 percent by increasing one percent in the value of electrical conductivity (EC). This implies that groundwater become unfit for irrigation as EC value increases (greater than $1.5 \mathrm{dS} / \mathrm{m}$ ) and over utilization of poor quality groundwater resulted in stunted plant growth; destroy the soil structure and low yield. Many researchers $[10,45-47,52]$ found that the poor-quality groundwater reduced the expected yield of crops.

The excess to extension services is included as dummy in the model having value 1 for excess to extension services and 0 otherwise. The coefficient of this variable is shown to have positive and highly significant impact on the gross value of cotton product. This implies that most of cotton farmers have strong linkages, regular contact with extension agents and easy access to extension services in the study area. The result of this variable is a priori, and literature supports that access to extension services have positive impact on cotton yield [10], resource use efficiency [16,49]. Similarly, the dummy variable of adopters of CSA in cotton production having value 1 for adopters and 0 otherwise is also regressed on gross value of cotton product. The results show that CSA have positive and highly significant impact on the gross value of cotton product. The results explained that adopters of CSA in cotton production have 13 percent higher yield than conventional cotton farmers. Many researchers [24,34,38-41]. Found that CSA practices and technologies had proved to energy and input efficient, increase production and farm income, and address the emerging environmental problems.

The adoption of new agricultural technologies had significant impact on agricultural productivity $[10,12,32,38,43]$ and resource use efficiency [16]. Implications of the results are that conventional cotton farmers are less productive due to excessive and inefficient use of external inputs; cotton yield can be improved by adapting CSA practices and technologies.

The entire results showed the absolute advantage of CSA over conventional cotton farming. Hence, cotton production by using CSA practices and technologies is financially, environmentally and socially far better than conventional cotton growing. The $\mathrm{R}^{2}$ value of the model is 0.715 , indicating that 71.5 percent variation in the gross value of cotton product is explained by the explanatory variables included in the model. The result of this model is adequate, and literature supports that the variables included had significant impact on cotton and wheat yield [10,45,47].

\subsection{Why Some Farmers Adopt CSA While Other Did Not?}

\subsubsection{Advantages of CSA Practices and Technologies}

In this study, adopters of CSA in cotton production were directly asked to give main advantages of CSA (Figure 3). Majority of the adopters of CSA (95 percent) reported that the CSA increased the productivity compared to conventional agriculture. The analysis of benefit cost already revealed that the adopters of CSA in cotton production have 13 percent higher yield than conventional cotton farmers (Table 4). The second most important advantage (86 percent) of CSA adoption uses less of external inputs and getting higher yield.

The analysis of input use revealed that adopters of CSA in cotton production use significantly less amount of external inputs compared to conventional cotton farmers (Table 3). Similarly, environmental friendly and resilient to climate change is the third most important advantage (74 percent) of CSA 
practices and technologies because the adopters of CSA are using external inputs efficiently. This implies that CSA plays a significant role in the sustainability of cotton production.

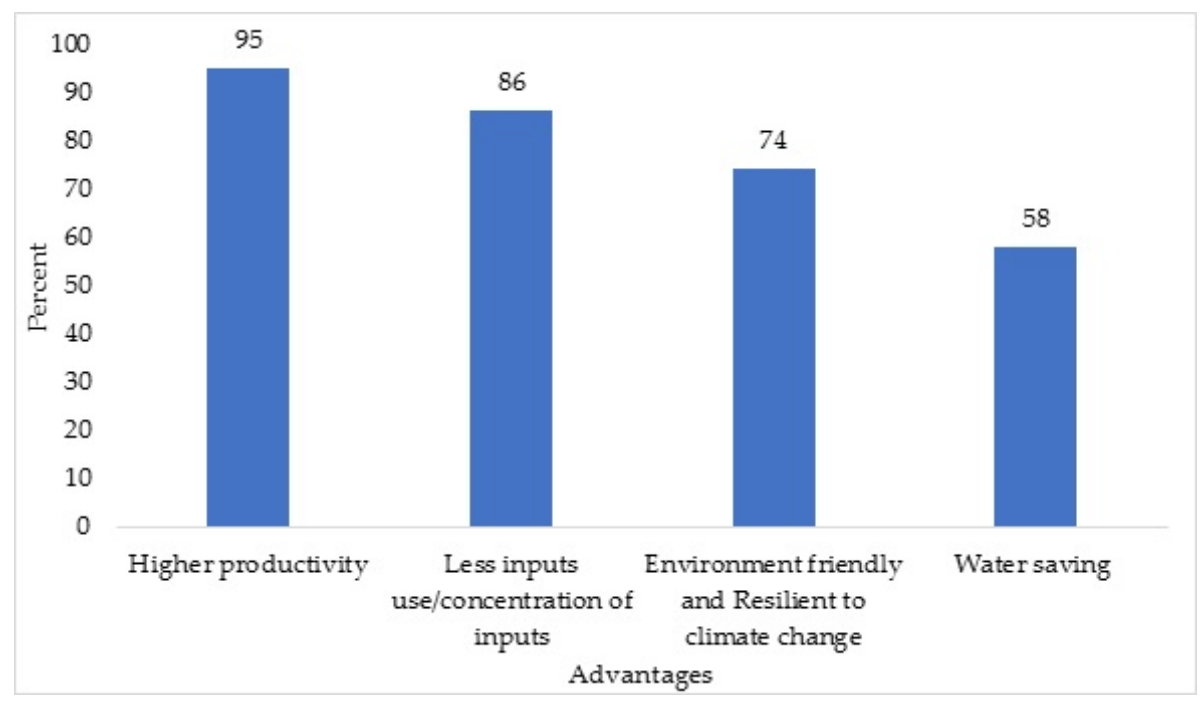

Figure 3. Advantages of Climate Smart Agriculture (CSA) (Multiple responses).

The pests and disease attack are minimum due to low humidity and evapotranspiration. Another advantage given by the adopters of CSA is that the significant amount of water can be saved by using CSA practices and technologies in cotton production (58 percent). The adopters of CSA produced higher water productivity compared to conventional cotton farmers. These results again strengthened by the findings of analysis of input use.

\subsubsection{Reasons for Adoption of CSA}

The adopters of CSA in cotton production were also asked to give main reasons for adopting CSA in cotton production (Figure 4). Majority of the farmer reported that the main reasons of adopting CSA practices and technologies are climate change, limited supply of canal water, drought-prone, massive groundwater extraction, rapidly declining water table and increasing soil salinity over the time. Majority of the adopters of CSA (84 percent) reported that the main reason of adopting CSA is climate change. Other main reasons of adopting CSA are limited supply of canal water (73 percent) and rapidly declining water table (47 percent) over the time in the study area.

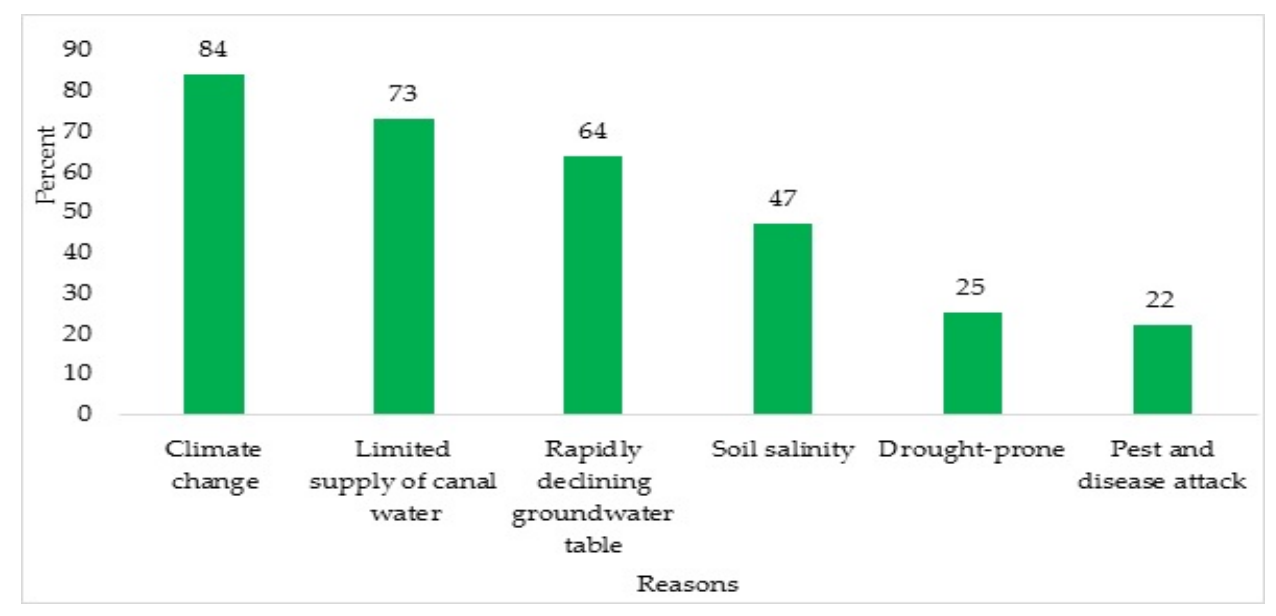

Figure 4. Reasons for adoption of CSA (Multiple responses). 


\subsubsection{Reasons for Not Adopting CSA}

The findings of the study show that CSA is far better than convention agriculture in terms of higher productivity, net returns and resource use efficiency but still convention agricultural practices are common among cotton growers in Punjab. Therefore, this study also asked the conventional cotton farmers to give main reasons for not adopting CSA practices and technologies in cotton production (Figure 5). Majority of the farmers (78.5 percent) have no perfect information (technical know-how, certified seed and pesticide sources and how to implement in fields) about CSA practices and technologies. Many convention cotton farmers (72 percent) reported that limited access to CSA technologies is the second most important reason for not adopting CSA practices and technologies. Due to this reason conventional cotton farmers continued using conventional agricultural practices. However, only 57 percent farmers reported financial constraint as a reason for not adopting CSA practices and technologies. Additionally, very small percentage of conventional cotton farmers reported that they are not interested in CSA as they perceived that their knowledge of agricultural practices is far better than the practices developed and promoted by scientist.

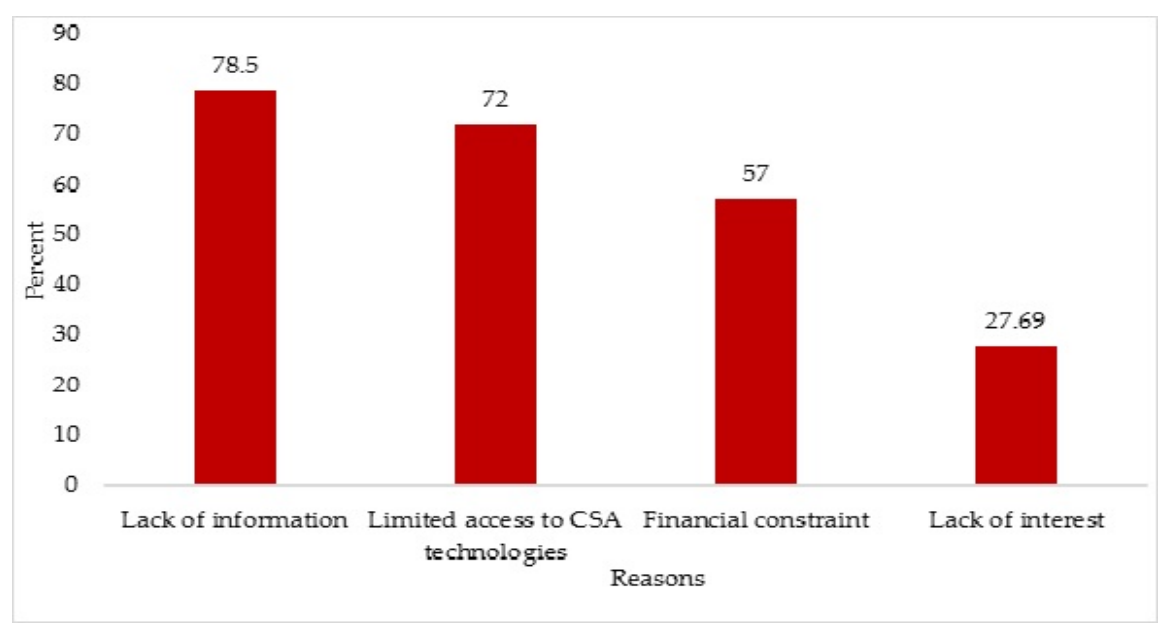

Figure 5. Reasons for not adopting CSA in cotton production (multiple responses).

\subsubsection{Ranking of Willingness to Adopt CSA by Conventional Cotton Farmers}

Additionally, the conventional cotton farmers were also asked to rank their willingness to adopt CSA practices and technologies in cotton production. Table 6 shows the ranking of CSA that conventional cotton farmers are willing to adopt. The table is only showing the first ranked option by the convention cotton farmers. Results of the ranking options made it clear that majority of the conventional cotton farmers (62 percent) are willing to adopt knowledge-smart i.e., certified seed technology of CSA and they desired for improvement in resource use efficiency and yield by adapting CSA. Similarly, many farmers (28 percent) are also willing to adopt water-smart practices and technologies of CSA. A possible solution could be providing CSA technologies at subsidized rate in the cotton growing areas on priority base.

Table 6. Ranking of willingness to adopt CSA by conventional cotton farmers (first response).

\begin{tabular}{ccc}
\hline Adaptation Options of CSA & Percentage (\%) & Rank \\
\hline Knowledge-smart & 62 & I \\
Water-smart & 28 & II \\
Carbon-smart & 8 & III \\
Energy-smart & 2 & IV \\
\hline
\end{tabular}

Source: Own calculation from survey data, 2017. 


\subsubsection{Mix of CSA Adoption Practices and Technologies among Adopters}

In the study area, the adoption of CSA practices and technologies as a combination has been increasing over the years, while the rate of adoption of individual CSA practice and technology is decreasing over the time (Figure 6). There was a significant increase in the percentage of adopters of CSA during las five years. The results show that all adopters of CSA were using knowledge, water, energy and carbon-smart practices and technologies in 2016 compared with the year 2015 (79 percent). Most of the farmers hired CSA technologies from Agricultural Service Providers (ASPs).

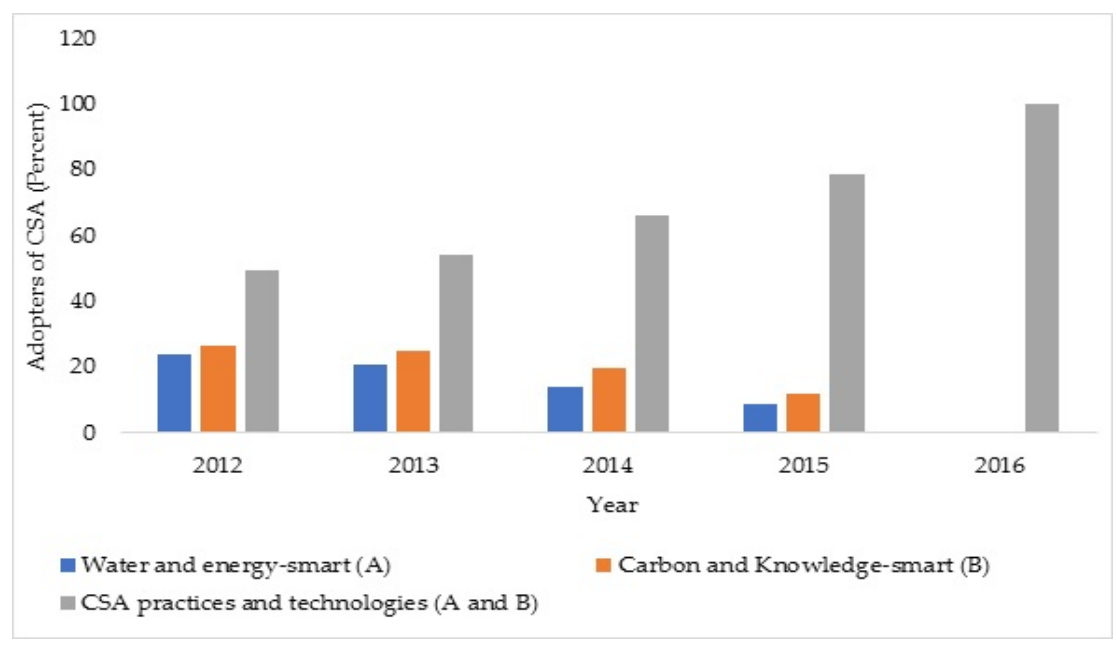

Figure 6. Mix of CSA adoption practices and technologies among adopters.

\subsubsection{Major Findings of Focus Group Discussions (FGDs)}

Major findings of FGDs are presented in Appendix A (Table A1). Majority of the farmers reported that the main reason of using CSA practices and technologies were limited supply of canal water, climate change, drought-prone, massive groundwater extraction, rapidly declining water table and increasing soil salinity over the time. More than 50 percent farmers of each villages are using the combination of water-smart, energy-smart, carbon-smart and knowledge-smart practices of CSA at their own farm in the study area. The results show that CSA practices and technologies, increase resilience to climate change, improves the farm productivity (22-30 percent) as well as livelihoods of cotton farmers. Some conventional cotton farmers (10-14 percent) destroy their cotton crops after first picking due to abrupt weather changes, severe insect pest attack and poor management practices.

\section{Conclusions}

The study investigated the financial performance and impact of climate-smart agriculture through sustainable water use management on cotton production in Lower Bari Doab Canal (LBDC) irrigation system of Punjab, Pakistan. In the study area, cotton farmers are using various CSA practices and technologies to counter the adverse impacts of climate change. The study found that main reasons of adopting CSA practices and technologies are limited supply of canal water, climate change, drought-prone, massive groundwater extraction, rapidly declining water table and increasing soil salinity over the time. The results of the analysis revealed that uniform germination, higher yield and financial returns, concentration of inputs, and increase in resource use efficiency are the main advantages of CSA. The results of the analysis also revealed some interesting factors i.e., CSA, excess to extension services have positive association with gross value of cotton product, and the negative association between groundwater quality and gross value of cotton product. The entire results showed the absolute advantage of CSA over conventional cotton farming. Hence, cotton production by using CSA practices and technologies is financially, environmentally and socially far better than conventional 
cultivation of cotton. Consequently, these CSA practices and technologies in the cotton growing area of Punjab and Sindh province would benefit many cotton farmers and significantly reduced the negative impact of climate change and variability on cotton-wheat cropping system in Pakistan. Therefore, the results of the analysis exposed some thought-provoking facts, which are unique in the context of Pakistan and also have significant policy implications.

The study suggested recommendations for policymakers, farmers and other stakeholders to promote CSA in cotton cultivation. These policy implications will improve crop productivity, increase net returns as thus raise livelihood of farmers.

- One of the reason of poor cotton yield is the non-availability of certified seed at a wider scale as only 12 percent farmers are using certified seed. The government should make certain arrangements for the preparation and judicious distribution of certified cotton seed among farmers at their door step to promote CSA in cotton growing areas of Punjab. The progressive farmers can be taken on board for the production and distribution of certified seed in the vicinity at market price.

- The government of Punjab is providing 50 percent subsidy on agricultural implements to farmers and Agricultural Service Providers (ASPs). It is advised that bed planters and laser land leveler should be included in the list of subsidized implements. The provision of these implements should be prioritized in cotton growing and water scared areas of Punjab.

- Awareness campaign about benefits of CSA practices and technologies need to be launched through print and electronic media and apps on smart phones in cotton growing areas. The success stories need to be demonstrated and disseminated, showing all the necessary measures to be adopted for sustainable farming, using CSA. Government can establish farmer's field school and give necessary training to farmers, NGOs representatives, local leaders and ASPs regarding the use of water-smart, energy-smart, carbon-smart and knowledge-smart practices and technologies of CSA.

- Another important reason of low adoption rate of CSA is limited access to farm services (e.g., greater availability of resources, easy access to credit, market and agricultural extension services). The low adoption rate of CSA calls for major reforms in agricultural development policies and strategies. Access to above stated farm services can be the major drivers for adoption of CSA, particularly for small and marginalized farmers. That will provide incentives for farmers to use CSA practices and technologies which would play a role in rural poverty reduction and modernization of agriculture.

- Over the time, advisory services on climate change, and CSA practices and technologies remained unsatisfactory. Because of this poor performance, cotton farmers in Pakistan are experiencing low productivity, poor resource use efficiency and excessive use of external inputs. Therefore, a need arises for enhancing the training opportunities for all stakeholders (agricultural extension agents, agricultural service providers, progressive farmers, community representatives and public and private water related agencies) about climate change, and CSA practices and technologies.

In addition to the contributions of this paper, there are several limitations that are worth mentioning. Although the sample size of conventional cotton farmers was small compared to adopters of CSA and survey was conducted in two districts with limited supply of canal water, climate change, drought-prone, massive groundwater extraction, rapidly declining water table and increasing soil salinity issues, our estimations are based on cross sectional data. Further, the target respondents in our survey are both adopters of CSA and conventional cotton farmers. A large sample size can be taken into count and other management practices can also be considered in future studies. Additionally, study can also be conducted in the areas where cotton crop is not badly affected by abrupt weather changes.

Author Contributions: The research was designed, performed and analyzed by M.A.I. who also prepared the first draft with valuable input from S.H.; R.C.; C.M. and A.A.; M.A. revised and rewrote the article with substantial input. All authors read and approved the final manuscript. 
Acknowledgments: The first author acknowledged the support for this research work provided by the Higher Education Commission (HEC) of Pakistan, through a Ph.D. indigenous scholarship granted to him. This research was also supported (Data collection and funds for covering the cost to publish in open access) by the Australian Centre for International Agricultural Research (ACIAR) at Charlus Sturt University, Australia and University of Agriculture, Faisalabad, Pakistan by the Australian Government under project No. LWR036.

Conflicts of Interest: The authors declare no conflict of interest.

\section{Appendix A}

Table A1. Major findings of Focus Group Discussions (FGDs).

\begin{tabular}{|c|c|c|c|c|}
\hline \multirow{2}{*}{ Variables } & \multicolumn{4}{|c|}{ Study Area } \\
\hline & \multicolumn{2}{|c|}{ Sahiwal (5L) } & \multicolumn{2}{|c|}{ Khanewal (2R/10R) } \\
\hline Education (Average Schooling Years) & \multicolumn{2}{|c|}{6.5} & \multicolumn{2}{|c|}{5.5} \\
\hline Participants (Number) & \multicolumn{2}{|c|}{27} & \multicolumn{2}{|c|}{30} \\
\hline Average land holding size (Acre) & \multicolumn{2}{|c|}{$\begin{array}{c}\text { Majority of the farmers have less } \\
\text { than } 12 \text { acres }\end{array}$} & \multicolumn{2}{|c|}{$\begin{array}{c}\text { Majority of the farmers have less } \\
\text { than } 12 \text { acres }\end{array}$} \\
\hline Soil quality/Land type & \multicolumn{2}{|c|}{ Fertile and good quality } & \multicolumn{2}{|c|}{ Fertile and good quality } \\
\hline Land rent per year (PKR/acre) & \multicolumn{2}{|c|}{23,500} & \multicolumn{2}{|c|}{22,500} \\
\hline Location of participants with respect to distributary & \multicolumn{2}{|c|}{ Head, Middle and Tail } & \multicolumn{2}{|c|}{ Head, Middle and Tail } \\
\hline Groundwater quality & \multicolumn{2}{|c|}{ Fit to marginal fit } & \multicolumn{2}{|c|}{ Fit to marginal fit and unfit at tail } \\
\hline Bore depth & \multicolumn{2}{|c|}{$53.34 \mathrm{~m}$} & \multicolumn{2}{|c|}{$57.91 \mathrm{~m}$} \\
\hline Groundwater table level & \multicolumn{2}{|c|}{$16.50 \mathrm{~m}$} & \multicolumn{2}{|c|}{$19.80 \mathrm{~m}$} \\
\hline Tubewells Type & \multicolumn{2}{|c|}{$\begin{array}{l}\text { Tractor operated and } \\
3 \text { electric tubewells }\end{array}$} & \multicolumn{2}{|c|}{$\begin{array}{l}\text { Tractor operated and } \\
4-5 \text { electric tubewells }\end{array}$} \\
\hline Main crops & \multicolumn{2}{|c|}{ Wheat, maize and cotton } & \multicolumn{2}{|c|}{ Wheat and cotton } \\
\hline Water course lining (percent) & \multicolumn{2}{|c|}{33} & \multicolumn{2}{|c|}{33} \\
\hline Groundwater treatment methods & \multicolumn{2}{|c|}{ FYM, conjunctive use and Gypsum } & \multicolumn{2}{|c|}{ FYM, conjunctive use and Gypsum } \\
\hline Canal water supply during Kharif (percent) & & & & \\
\hline FGDs participants response (percent) & Yes & No & Yes & No \\
\hline Conjunctives use & 76.5 & 23.5 & 81.5 & 19.5 \\
\hline Groundwater market & 55.5 & 44.5 & 67.5 & 32.5 \\
\hline $\begin{array}{l}\text { Access to farm services (credit, extension, } \\
\text { markets, farm market roads) }\end{array}$ & 62.5 & 37.5 & 58.5 & 41.5 \\
\hline Have groundwater quality worsen over the time? & 72.5 & 27.5 & 75 & 25 \\
\hline $\begin{array}{l}\text { Have groundwater table level declined over the time } \\
\text { table level? }\end{array}$ & 77 & 23 & 83 & 17 \\
\hline $\begin{array}{c}\text { Does poor quality groundwater worsen the head-tail } \\
\text { equity problem? }\end{array}$ & 56.5 & 43.5 & 59.5 & 40.5 \\
\hline $\begin{array}{l}\text { Does your farm productivity decrease over the time due } \\
\text { to said problems? }\end{array}$ & 92.5 & 7.5 & 95 & 5 \\
\hline FGDs participants response (percent) & Yes & No & Yes & No \\
\hline $\begin{array}{l}\text { Does your cost of production increased over the time } \\
\text { due to said problems? }\end{array}$ & 88.5 & 11.5 & 90.5 & 9.5 \\
\hline $\begin{array}{l}\text { Do you think temperature in your area increased } \\
\text { over the time? }\end{array}$ & 74.5 & 25.5 & 79.5 & 20.5 \\
\hline $\begin{array}{c}\text { Do you think your area received less rain fall } \\
\text { over the time? }\end{array}$ & 77.5 & 22.5 & 84.5 & 15.5 \\
\hline $\begin{array}{l}\text { Have your area received rain fall at the time of sowing } \\
\text { and harvesting? }\end{array}$ & 45 & 55 & 40 & 60 \\
\hline $\begin{array}{l}\text { Have your area affected by climate change } \\
\text { over the time? }\end{array}$ & 78 & 22 & 82 & 18 \\
\hline $\begin{array}{c}\text { Does climate change have negative impact } \\
\text { on agriculture? }\end{array}$ & 86 & 14 & 88 & 12 \\
\hline $\begin{array}{l}\text { Does your farm income decrease over the time } \\
\text { due to climate change? }\end{array}$ & 77 & 23 & 81 & 19 \\
\hline $\begin{array}{l}\text { Does you destroy your crop due to abrupt change in } \\
\text { weather and insect pest attack? }\end{array}$ & 14 & 86 & 10 & 90 \\
\hline
\end{tabular}


Table A1. Cont.

\begin{tabular}{|c|c|c|c|c|}
\hline \multirow{2}{*}{ Variables } & \multicolumn{4}{|c|}{ Study Area } \\
\hline & \multicolumn{2}{|c|}{ Sahiwal (5L) } & \multicolumn{2}{|c|}{ Khanewal (2R/10R) } \\
\hline \multicolumn{5}{|c|}{$\begin{array}{l}\text { Mitigation measures adopted by farmers at farm in response to declining groundwater table, limited canal water supply, } \\
\text { increasing soil salinity and climate change }\end{array}$} \\
\hline Farmers aware about CSA & 57.5 & 42.5 & 52.5 & 47.5 \\
\hline Have you practiced water-smart practices? & 76.5 & 24.5 & 78.5 & 21.5 \\
\hline Have you practiced energy-smart practices? & 66 & 34 & 61 & 39 \\
\hline Have you practiced carbon-smart practices? & 54 & 46 & 63 & 37 \\
\hline Have you practiced knowledge-smart practices? & 58 & 42 & 50.5 & 49.5 \\
\hline $\begin{array}{l}\text { Have you practiced nutrient and } \\
\text { weather-smart practices? }\end{array}$ & 8 & 92 & 5.5 & 94.5 \\
\hline Does CSA reduce the use of external inputs? & 82 & 18 & 80 & 20 \\
\hline $\begin{array}{l}\text { Does CSA practices and technologies resilient to } \\
\text { climatic variations? }\end{array}$ & 79 & 21 & 75 & 25 \\
\hline Does CSA reduce the cost of production? & 54 & 46 & 52 & 48 \\
\hline Does CSA increase the yield? & 77 & 23 & 79.5 & 21.5 \\
\hline $\begin{array}{l}\text { Does CSA decrease soil salinity and increasing } \\
\text { groundwater table level? }\end{array}$ & 69 & 31 & 71 & 29 \\
\hline Does you have Limited information about CSA & 18.5 & 81.5 & 23 & 77 \\
\hline Does CSA availability is limited in your area? & 74 & 26 & 73 & 27 \\
\hline How much your yield Increase due to CSA (percent)? & \multicolumn{2}{|c|}{$22-30$} & \multicolumn{2}{|c|}{$18-25$} \\
\hline
\end{tabular}

Source: Own calculation from Focus Group Discussions (FGDs), 2017.

\section{References}

1. GOP. Agricultural Statistics of Pakistan 2016-17; Ministriy of Finance: Islamabad, Pakistan, 30 June 2007. Available online: http://www.finance.gov.pk/survey_1617.html (accessed on 7 November 2017).

2. Waqas, A.; Hong, C.; Maroof, A.M.; Rana, R.M.; Saima, A.; Ali, A. Comparison of Organic Farming and Conventional Farming In the Punjab, Pakistan. Int. J. Sci. Eng. Res. 2017, 8, 29-38.

3. Bank, C.W. Climate-Smart Agriculture in Pakistan. CSA Country Profiles for Asia Series. International Center for Tropical Agriculture (CIAT); The World Bank: Washington, DC, USA, 2017; 28p, Available online: http: / /hdl.handle.net/10568/83340 (accessed on 21 December 2017).

4. Abid, M.; Ngaruiya, G.; Scheffran, J.; Zulfiqar, F. The role of social networks in agricultural adaptation to climate change: Implications for sustainable agriculture in Pakistan. Climate 2017, 5, 1-21. [CrossRef]

5. Abid, M.; Scheffran, J.; Schneider, U.A.; Ashfaq, M. Farmers' perceptions of and adaptation strategies to climate change and their determinants: The case of Punjab province, Pakistan. Earth Syst. Dyn. 2015, 6, 225-243. [CrossRef]

6. Abid, M.; Schneider, U.A.; Scheffran, J. Adaptation to climate change and its impacts on food productivity and crop income: Perspectives of farmers in rural Pakistan. J. Rural Stud. 2016, 47, 254-266. [CrossRef]

7. Khan, M.; Akram, N.; Husnain, M.I.U.; Haq Padda, I.U.; Qureshi, S.A. Poverty-environment nexus: Use of pesticide in cotton zone of Punjab, Pakistan. Int. J. Sustain. Dev. 2011, 4. [CrossRef]

8. Wada, Y.; van Beek, L.P.H.; van Kempen, C.M.; Reckman, J.W.T.M.; Vasak, S.; Bierkens, M.F.P. Global depletion of groundwater resources. Geophys. Res. Lett. 2010, 37. [CrossRef]

9. Watto, M.A.; Mugera, A.W. Irrigation water demand and implications for groundwater pricing in Pakistan. Water Policy 2015, 18, 565-585. [CrossRef]

10. Punthakey, E.F.; Khan, M.R.; Niaz, R.; Muhammad Riaz, M.J.; Zakir, G.; Usman, M.; Amin, M.; Ahmad, R.N.; Culas, R.; Baig, I.A.; et al. Optimising Canal and Groundwater Management to Assist Water User Associations in Maximizing Crop Production and Managing Salinisation in Australia and Pakistan; Australian Centre for International Agricultural Research (ACIAR): Canberra, Australia, 2016; pp. 1-32. Available online: https:/ / researchoutput.csu.edu.au/en/publications/optimising-canal-and-groundwatermanagement-to-assist-water-user (accessed on 23 August 2017).

11. Qureshi, A.S.; McCornick, P.G.; Sarwar, A.; Sharma, B.R. Challenges and Prospects of Sustainable Groundwater Management in the Indus Basin, Pakistan. Water Resour. Manag. 2009, 24, 1551-1569. [CrossRef] 
12. Ali, A.; Erenstein, O. Assessing farmer use of climate change adaptation practices and impacts on food security and poverty in Pakistan. Clim. Risk Manag. 2017, 16, 183-194. [CrossRef]

13. Makhdum, A.H.; Khan, H.N.; Ahmad, S. Reducing cotton footprints through implementation of better management practices in cotton production; a step towards better cotton initiative. In Proceedings of the Fifth Meeting of the Asian Cotton Research and Development Network, Lahore, Pakistan, 23-26 February 2011; pp. 1-18. Available online: https://www.icac.org/tis/regional_networks/asian_network/meeting_5/ (accessed on 4 January 2018).

14. Watto, M.A.; Mugera, A.W. Econometric estimation of groundwater irrigation efficiency of cotton cultivation farms in Pakistan. J. Hydrol. Reg. Stud. 2015, 4, 193-211. [CrossRef]

15. Zulfiqar, F.; Thapa, G.B. Is 'Better cotton' better than conventional cotton in terms of input use efficiency and financial performance? Land Use Policy 2015, 52, 136-143. [CrossRef]

16. Zulfiqar, F.; Datta, A.; Thapa, G.B. Determinants and resource use efficiency of "better cotton": An innovative cleaner production alternative. J. Clean. Prod. 2017, 166, 1372-1380. [CrossRef]

17. Nazli, H.; Orden, D.; Sarker, R.; Meilke, K. Bt Cotton Adoption and Wellbeing of Farmers in Pakistan. In Proceedings of the International Association of Agricultural Economists (IAAE) Triennial Conference, Foz do Iguaçu, Brazil, 18-24 August 2012; pp. 1-26. Available online: ageconsearch.umn.edu/bitstream/ 126172/ (accessed on 3 February 2018).

18. Raza, A.; Ahmad, M. Analysing the Impact of Climate Change on Cotton Productivity in Punjab and Sindh, Pakistan; Pakistan Institute of Development Economics (PIDE): Islamabad, Pakistan, 2015; p. 32. Available online: https:/ / mpra.ub.uni-muenchen.de/72867/ (accessed on 29 January 2018).

19. Zhu, T.; Ringler, C.; Iqbal, M.M.; Sulser, T.B.; Goheer, M.A. Climate Change Impacts and Adaptation Options for Water and Food in Pakistan: Scenario Analysis Using an Integrated Global Water and Food Projections Model. Water Int. 2013, 38, 651-669. [CrossRef]

20. Iqbal, M.; Ahmad, M.; Mustafa, G. Impact of Farm Households' Adaptation on Agricultural Productivity: Evidence from Different Agro-Ecologies of Pakistan. Climate Change Working Paper Series No. 5. MPRA Paper No. 72863. 2015, pp. 1-25. Available online: https://mpra.ub.uni-muenchen.de/id/eprint/72863 (accessed on 7 February 2018).

21. Watto, M. Measuring Groundwater Irrigation Efficiency in Pakistan: A DEA Approach Using the Sub-vector and Slack-based Models. In Proceedings of the 57th Australian Agricultural and Resource Economics Society Annual Conference, Sydney, Australia, 5-8 February 2013; pp. 1-35.

22. FAO. "Climate-Smart" Agriculture Policies, Practices and Financing for Food Security, Adaptation and Mitigation; Food and Agriculture Organization of the United State of America (FAO): Rome, Italy, 2010; pp. 1-49. Available online: http:/ / www.fao.org/docrep/013/i1881e/i1881e00.htm (accessed on 21 December 2017).

23. Khatri-Chhetri, A.; Aggarwal, P.K.; Joshi, P.K.; Vyas, S. Farmers' prioritization of climate-smart agriculture (CSA) technologies. Agric. Syst. 2017, 151, 184-191. [CrossRef]

24. Khatri-Chhetri, A.; Aryal, J.P.; Sapkota, T.B.; Khurana, R. Economic benefits of climate-smart agricultural practices to smallholder farmers in the Indo-Gangetic Plains of India. Curr. Sci. 2016, 110, 1251-1256. [CrossRef]

25. Branca, G.; McCarthy, N.; Lipper, L.; Jolejole, M.C. Climate Smart Agriculture: A Synthesis of Empirical Evidence of Food Security and Mitigation Benefits from Improved Cropland; Food and Agriculture Organization of the United Nations (FAO): Rome, Italy, 2011; Available online: http:/ /hdl.handle.net/10568/33460 (accessed on 3 February 2018).

26. Jat, R.K.; Sapkota, T.B.; Singh, R.G.; Jat, M.L.; Kumar, M.; Gupta, R.K. Seven years of conservation agriculture in a rice-Wheat rotation of Eastern Gangetic Plains of South Asia: Yield trends and economic profitability. Field Crops Res. 2014, 164, 199-210. [CrossRef]

27. Lipper, L.; Thornton, P.; Campbell, B.M.; Baedeker, T.; Braimoh, A.; Bwalya, M.; Caron, P.; Cattaneo, A.; Garrity, D.; Henry, K.; et al. Climate-smart agriculture for food security. Nat. Clim. Chang. 2014, 4, 1068-1072. [CrossRef]

28. Sapkota, T.B.; Jat, M.L.; Aryal, J.P.; Jat, R.K.; Khatri-Chhetri, A. Climate change adaptation, greenhouse gas mitigation and economic profitability of conservation agriculture: Some examples from cereal systems of Indo-Gangetic Plains. J. Integr. Agric. 2015, 14, 1524-1533. [CrossRef]

29. Challinor, A.J.; Watson, J.; Lobell, D.B.; Howden, S.M.; Smith, D.R.; Chhetri, N. A meta-analysis of crop yield under climate change and adaptation. Nat. Clim. Chang. 2014, 4, 287-291. [CrossRef] 
30. Easterling, W.; Aggarwal, P.; Batima, P.; Brander, K.; Erda, L.; Howden, M.; Kirilenko, A.; Morton, J.; Soussana, J.F.; Schmidhuber, J.; et al. Climate Change 2007: Impacts, Adaptation and Vulnerability; Cambridge University Press: Cambridge, UK, 2007; p. 40. Available online: http:/ /www.ipcc.ch/publications_and_ data/publications_ipcc_fourth_assessment_report (accessed on 6 February 2018).

31. Finger, R.; Schmid, S.; Zurich, E. Modeling agricultural production risk and the adaptation to climate change. In 101st EAAE Seminar 'Management of Climate Risks in Agriculture; Archive, M.P.R., Ed.; MPRA Paper No. 3943; Munich Personal RePEc Archive: Berlin, Germany, 2007; pp. 1-22. Available online: http:/ / mpra.ub.uni-muenchen.de/3943/ (accessed on 6 February 2018).

32. Hussain, M.; Ashfaq, M.; Ali, A.; Hassan, S.; Imran, M.A. An econometric analysis of bed-furrow irrigation for cultivatedwheat in irrigated areas of Punjab, Pakistan. Pak. J. Agric. Sci. 2017, 54, 467-474. [CrossRef]

33. Xiong, W.; van der Velde, M.; Holman, I.P.; Balkovic, J.; Lin, E.; Skalský, R.; Porter, C.; Jones, J.; Khabarov, N.; Obersteiner, M. Can climate-smart agriculture reverse the recent slowing of rice yield growth in China? Agric. Ecosyst. Environ. 2014, 196, 125-136. [CrossRef]

34. Sapkota, T.B.; Majumdar, K.; Jat, M.L.; Kumar, A.; Bishnoi, D.K.; McDonald, A.J.; Pampolino, M. Precision nutrient management in conservation agriculture based wheat production of Northwest India: Profitability, nutrient use efficiency and environmental footprint. Field Crops Res. 2014, 155, 233-244. [CrossRef]

35. Naresh, R.K.; Singh, S.P.; Misra, A.K.; Tomar, S.S.; Kumar, P.; Kumar, V.; Kumar, S. Evaluation of the laser leveled land leveling technology on crop yield and water use productivity in Western Uttar Pradesh. Afr. J. Agric. Res. 2014, 9, 473-478. [CrossRef]

36. Olayide, O.E.; Tetteh, I.K.; Popoola, L. Differential impacts of rainfall and irrigation on agricultural production in Nigeria: Any lessons for climate-smart agriculture? Agric. Water Manag. 2016, 178, 30-36. [CrossRef]

37. Gathala, M.K.; Ladha, J.K.; Kumar, V.; Saharawat, Y.S.; Kumar, V.; Sharma, P.K.; Sharma, S.; Pathak, H. Tillage and crop establishment affects sustainability of South Asian rice-wheat system. Agron. J. 2011, 103. [CrossRef]

38. Aryal, J.P.M.; Bhatia, M.; Jat, M.L.; Sidhu, H.S. Impacts of laser land leveling in rice-wheat systems of the north-western indo-gangetic plains of India. Food Secur. 2015, 7, 725-738. [CrossRef]

39. Kumar, V.; Saharawat, Y.S.; Gathala, M.K.; Jat, A.S.; Singh, S.K.; Chaudhary, N.; Jat, M.L. Effect of different tillage and seeding methods on energy use efficiency and productivity of wheat in the Indo-Gangetic Plains. Field Crops Res. 2013, 142, 1-8. [CrossRef]

40. Saharawat, Y.S.; Singh, B.; Malik, R.K.; Ladha, J.K.; Gathala, M.; Jat, M.L.; Kumar, V. Evaluation of alternative tillage and crop establishment methods in a rice-wheat rotation in North Western IGP. Field Crops Res. 2010, 116, 260-267. [CrossRef]

41. Saharawat, Y.S.; Ladha, J.K.; Pathak, H.; Malik, R.K.; Gathala, M.; Gupta, R.K. Validation of InfoRCT model for resource conserving technologies in rice-wheat system on productivity, income and environment. J. Soil Sci. Environ. Manag. 2011, 3, 9-22. [CrossRef]

42. Bakhsh, A.; Ashfaq, M.; Ali, A.; Hussain, M.; Rasool, G.; Haider, Z.; Faraz, R.H. Economic evaluation of different irrigation systems for wheat production in Rechna Doab, Pakistan. Pak. J. Agric. Sci. 2015, 52, 821-828. Available online: https:/ / www.pakjas.com.pk/papers/2487.pdf (accessed on 19 September 2016).

43. Latif, A.; Shakir, A.S.; Rashid, M.U. Appraisal of economic impact of zero tillage, laser land levelling and bed-furrow interventions in Punjab, Pakistan. Pak. J. Eng. Appl. Sci. 2013, 13, 65-81.

44. Zulfiqar, F.; Thapa, G.B. Determinants and intensity of adoption of "better cotton" as an innovative cleaner production alternative. J. Clean. Prod. 2018, 172, 3468-3478. [CrossRef]

45. Ashfaq, M.; Akram, M.; Baig, I.A.; Saghir, A. Impact of Groundwater on Wheat Production in District Jhang, Punjab, Pakistan. Sarhad J. Agric. 2009, 25, 121-125.

46. Hussain, I.; Mudasser, M.; Hanjra, M.A.; Amrasinghe, U.; Molden, D. Improving wheat productivity in Pakistan: Econometric analysis using panel data from chaj in the upper Indus Basin. Water Int. 2004, 29, 189-200. [CrossRef]

47. Shakoor, A.; Arshad, M.; Bakhsh, A.; Ahmed, R. GIS Based Assessment and Delineation og Groundwater Quality Zones and Its Impact on Agricultural Productivity. Pak. J. Agric. Sci. 2015, 52, 837-843.

48. Basharat, M. Integration of Canal and Groundwater to Improve Cost and Quality Equity of Irrigation Water in a Canal Command. Ph.D. Thesis, University of Engineering and Technology Lahore, Lahore, Pakistan, 2012. 
49. Watto, M.A.; Mugera, A.W. Measuring production and irrigation efficiencies of rice farms: Evidence from the Punjab province, Pakistan. Asian Econ. J. 2014, 28, 301-322. [CrossRef]

50. Javed, I.; Ghafoor, A.; Ali, A.; Imran, M.A.; Ashfaq, M. Margins and determinants of rice export from Pakistan to UAE market. Pak. J. Agric. Sci. 2015, 52, 557-563.

51. Shahroudi, S.M. Estimation of food substance small-scale production function. Int. J. Food Sci. Technol. 2012, 2, 15-19.

52. Hussain, M.; Farooq, M.; Shehzad, M.; Khan, M.B.; Wahid, A.; Shabir, G. Evaluating the performance of elite sunflower hybrids under saline conditions. Int. J. Agric. Biol. 2012, 14, 131-135. Available online: https:/ / www.researchgate.net/publication/265414796 (accessed on 18 April 2018).

2018 by the authors. Licensee MDPI, Basel, Switzerland. This article is an open access article distributed under the terms and conditions of the Creative Commons Attribution (CC BY) license (http://creativecommons.org/licenses/by/4.0/). 